\title{
Kötü huylu kemik tümörlerinde evreleme ve cerrahi tedavi prensipleri
}

\author{
Principles of staging and surgical treatment in malignant bone tumours
}

\author{
Yavuz Kabukçuoğlu, Merter Yalçınkaya, Sami Sökücü \\ Baltalimanı Kemik Hastalıkları Eğitim ve Araştırma Hastanesi, Ortopedi ve Travmatoloji Kliniği, İstanbul
}

\begin{abstract}
Kötü huylu kemik tümörlerinin tedavisindeki artan başarı ve yükselen sağkalım oranları, hem medikal onkoloji, hem radyasyon onkolojisi hem de ortopedik onkolojik cerrahideki gelişmeler eşliğinde ortaya çıkmıştır. Bu gelişmelerin ana aktörleri, histolojik incelemelerde yeni boyama tekniklerinin bulunması, moleküler biyolojinin ve genetik incelemelerinin devreye girmesi, onkolojik ilaçların ve rejimlerin değişmesi, hedefe yönelik tedavi modaliteleri, hızla gelişen ve değişen ortopedik implant seçeneklerinin beraberinde getirdiği karmaşık cerrahi girişimlerin varlığı gibi görünse de, başarının sırrı aslında yaklaşık 30 yıl önce ortaya konmuş olan temel onkolojik kuralların bugün daha iyi anlaşımış olması ve tedavilerin bu yönde değişmesinde yatmaktadır: uygun biyopsi, doğru tanı, uygun evreleme ve temiz cerrahi sınırlar. Kötü huylu kemik tümörlerinin tedavisinde başarılı sonuç elde etmenin temelinde yer aldığını düşündüğümüz bu dört ana başlık ve uyulması gereken temel kurallar özet olarak bu derlemede yer almaktadır.
\end{abstract}

Anahtar sözcülkler: kötü huylu; kemik tümörleri; biyopsi; tümör evrelemesi; cerrahi tedavi
Increasing successful treatments and rising survival rates in malignant bone tumours have emerged in the presence of the remarkable progresses obtained in medical oncology, radiation oncology and orthopaedic surgical oncology. Although it seems that the main actors of this progress are new staining techniques in histological examinations, utilization of molecular biology and genetic analysis, alteration of oncologic medications and regimes, targeted therapy modalities, sophisticated surgical interventions along with rapidly developing and changing orthopaedic implant options, the secret of the success lies actually in better understanding of basic oncological principles that have been demonstrated almost 30 years ago and changing of treatment methods in this direction: appropriate biopsy, accurate diagnosis, convenient staging and clear surgical margins. These four main topics which we think are the fundamentals for achieving successful results in the treatment of malignant bone tumours and principles that must be followed have been summarized in this review article.

Key words: malignant; bone neoplasms; biopsy; tumour staging; operative therapy

Evreleme sistemlerini doğru bir şekilde kullanabilmek için "kompartman" kavramını iyi anlamak gerekir. Ortopedik onkolojide kullanılan kompartman kavramı, klasik ortopedik tanımlamalar içerisinde yer alan ve normal bir insandaki kas ve iskelet sisteminin bölümlere ayrılmasına yardımcı olan kompartman tanımından farklı olarak; tümör uzantılarına doğal bir sınır yaratan anatomik yapıların veya boşlukların hepsine verilen isimdir. ${ }^{[2,6]}$ Bu tanımlamayı yapan Enneking'e göre doğal sınırdan kasıt; kortikal kemik, fasya, eklem kıkırdağı, eklem kapsülü, tendon ve tendon kılıfıdır. ${ }^{[2]}$ Bu kompartman dışındaki yağlı ve interstisyel dokular ise kompartman dışı olarak kabul edilir. ${ }^{[6]}$

Kortikal kemik ve fasya, içerdiği damarsal girişçıkış noktaları nedeniyle tümör tarafından aşılabilir

- Illetişim adresi: Doç. Dr. Yavuz Kabukçuoğlu, Metin Sabancı Baltalimanı Kemik Hastalıkları Eğitim ve Araştırma Hastanesi, Ortopedi ve Travmatoloji Kliniği, Rumeli Hisarı Cad. No: 62,34470, Baltalimanı, Sarıyer, İstanbul Tel: 0212 - 32370 75/1101 e-posta: ykabukcuoglu@yahoo.com

- Geliș tarihi: 17 Haziran 2014 Kabul tarihi: 17 Haziran 2014 
durumdadır. Buna karşın, eklem kıkırdağı, hiç vasküler giriş-çıkış noktası içermediğinden dolayı tümöral oluşumlara en dirençli yapılardır. Periost, sinoviyal membranlar ve ana sinirlerin kılıfları, oldukça ince bariyerler olsa da, rölatif olarak tümöral oluşumlara sınır oluşturabilirler. Eklem kapsülünün, sinoviyanın, bağların ve tendonların epifize, apofize veya metafize bağlandığı noktalarda ise tümöral oluşumlara bariyer oluşturan tek yapı damarsal giriş-çıkış içeren ince kemik korteksidir ve bu nedenle tümöral dokular bu yapılardan kansellöz kemiğe ulaşabilir. ${ }^{[2]}$

Kemik tümörlerinin temel görüntüleme yöntemi düz radyografilerdir. Ayırıcı tanı elde etmede halen altın standart olarak kabul edilmektedir. ${ }^{[3,7]}$ Kemik tümörlerinde hastanın tıbbi öyküsü, fizik muayene bulguları ve düz radyografi ile elde edilen bilgiler ile olguların \%80'inden fazlasında tanı konabilir. ${ }^{[3]}$ Düz radyografide bir lezyon tespit edildiğinde kemik harabiyetinin boyutunu anlamak için uygulanması gereken görüntüleme yöntemi bilgisayarlı tomografi (BT) olmalıdır. ${ }^{[1,3]}$ Manyetik rezonans (MR) görüntüleme ise kemik tümörlerinin intramedüller bölgedeki ve kemik dışarısındaki yumuşak doku uzanım miktarını değerlendirmede BT'den üstündür. ${ }^{[1,3]}$ Kemik sintigrafisi, metastatik kitle varlığını (renal hücreli karsinom ve tiroid karsinomu hariç) ve poliostotik kemik hastalığını araştırmak (multipl miyelom hariç), yumuşak doku sarkomlarının kemiğe yaptığı hasarın boyutunu görebilmek ve primer kemik sarkomlarının medüller uzanımını anlamak için yararlı olan, duyarlı ancak özgül olmayan bir inceleme yöntemidir;; ${ }^{[3,7]}$ iyi huylu - kötü huylu ayrımı yapamaz ve tümörün tam olarak son bulduğu noktayı belirlemekte yetersizdir. ${ }^{[1]}$ Temiz cerrahi sınır elde etmek adına, tutulumun sintigrafik olarak artmış olduğu yerden $6 \mathrm{~cm}$ proksimalde rezeksiyonu yapmak kabul edilmiş bir kuraldır. ${ }^{[3]}$ MR ile bu sınırlar daha kolay seçilebilir ve bu şekilde rezeksiyon sınırları daha da kısaltılabilir. Üç fazlı kemik sintigrafilerinin akım ve havuz fazlarındaki kemik tümörünün görüntüsü, kitlenin biyolojik aktivitesini anlamak ve hatta zaman zaman tanısını koymak için yararlıdır. Tümörün kemoterapiye vereceği yanıtı dolaylı olarak da anlamak sintigrafi ile mümkün olabilir. Kemik dışarısında büyük uzanımı olan kemik sarkomlarının ameliyatlarından önce, hem ameliyat planlamasını yapabilmek hem de çevresel vasküler yapıların yerleşimlerini anlamak için anjiyografiye de gerek duyulabilir. ${ }^{[3]}$

Tümörlerin düşük görülme insidansları, heterojen yapıları, öngörülemeyen davranışları ve prognostik değer taşıyan kavramlar konusundaki farklı görüşler nedeniyle yumuşak doku ve kemiğin sarkomlarında evrensel olarak kabul edilen tek bir evreleme yöntemi yoktur. ${ }^{[1,3,8]}$ Bazı evreleme sistemleri cerrahi stratejiye karar vermek için yararlı iken bazı sistemler prognoz hakkında iyi fikir verir. İyi bir evreleme sistemi, kullanımı pratik, tekrarlanabilir ve prognostik değeri olandır. ${ }^{[9]} \mathrm{En}$ sık kullanılan evreleme yöntemleri Enneking'in tanımladığı sistem ile Amerikan Eklem Komitesi (American Joint Committee - AJC) sistemidir. ${ }^{[1-3,5,10]}$ Enneking'in tanımladığı ve bugün halen kullanımda olan evreleme sistemi, Muskuloskeletal Tumor Society tarafindan düzenlenmiş olan evrelemedir. ${ }^{[1,9]}$

Enneking'in klasik evreleme sistemi, G, T ve $M$ harflerinden oluşan üç temel parametreye dayalıdır. ${ }^{[2,5]}$

G: Tümörün histolojik olarak gradını, yani derecesini ifade eder. G0 iyi huylu, G1 düşük gradlı kötü huylu, G2 yüksek gradlı kötü huylu anlamına gelir.

T: Tümörün anatomik uzanımını ifade eder. T0 iyi huylu bir tümörün gerçek bir kapsül ile çevrili olduğu, T1 iyi veya kötü huylu bir tümörün gerçek bir kapsülden çok, anatomik kompartman tarafından sınırlandığı ve T2 iyi veya kötü huylu bir tümörün kompartman dışından köken aldığı veya doğal sınırları aşarak kompartman dışına çıktığı anlamını taşır. Kemik tümöründe T'nin ne olduğuna daha önce tanımlanan görüntüleme yöntemleri ile karar verilir. ${ }^{[3]}$ Kemik tümörlerinde bu sınır, kemik korteksi ve kıkırdak olarak belirlenmiştir. Parosteal tümörler, T1 olarak kabul edilmektedir. [1]

M: Metastazı ifade eder. Metastaz bölgesel olabileceği gibi (skip veya lenf nodu şeklinde) uzak metastaz şeklinde de olabilir. M0 metastaz yokluğunu, M1 metastaz varlığını ifade eder.

İyi huylu kemik tümörlerinin evrelemesinde Arap rakamları kullanılırken, kötü huylu kemik tümörlerinin evreleri Roma rakamları ile ifade edilirler. ${ }^{[7,11]}$ ìy huylu kemik ve yumuşak doku tümörlerinde grad, her zaman G0'dır ve Evre 1 (latent, inaktif), Evre 2 (aktif) ve Evre 3 (agresif) olarak evrelendirilirler (Tablo 1). ${ }^{[5]}$ Değerlendirmede tümörün radyografik özellikleri ön planda tutulur. ${ }^{[9]}$ Her ne kadar iyi huylu kemik tümörler, tanımları gereği metastaz yapmayan kitleler olarak bilinseler de, lokal agresif kabul edilen dev hücreli kemik tümörü ve kondroblastomların nadir de olsa metastaz yapabilecekleri unutulmamalıdır. ${ }^{[9]}$

Kemik ve yumuşak doku sarkomları ise Evre I (\%25'den az metastaz şansı olan düşük gradlı malignite), Evre II (\%25'den fazla metastaz şansı olan yüksek gradlı malignite) ve Evre III (uzak organ veya lenf nodu metastazının olduğu tümörler) olarak evrelendirilirler (Tablo 2) ${ }^{[2,5,9]}$ Evre I ve II, tümörün kompartman içi (Tip A) veya dışı (Tip B) olmasına göre iki alt gruba ayrilırken, Evre III tümör derecesinin düşük veya yüksek olmasına göre $A$ ve $B$ olarak iki alt gruba ayrılır. ${ }^{[2]}$ Kompartman içi olan Tip A tümörlerde lokal kontrol şansı, kompartman dışı olan Tip $B$ tümörlere göre daha fazladır. Tip A tümörler tek bir kas lifi veya kemik 
Tablo 1. Enneking sistemine göre iyi huylu kemik tümörlerinin cerrahi evrelemesi

\begin{tabular}{ccccc}
\hline Evre & Grad & Uzanım & Metastaz & Tanım \\
\hline $\mathbf{1}$ & G0 & T0 & M0 & Latent veya inaktif \\
$\mathbf{2}$ & G0 & T0 & M0 & Aktif \\
$\mathbf{3}$ & G0 & T1-2 & M0-1 & Agresif
\end{tabular}

Tablo 2. Enneking sistemine göre kötü huylu kemik tümörlerinin cerrahi evrelemesi

\begin{tabular}{ccccc}
\hline Evre & Grad & Uzanım & Metastaz & Tanım \\
\hline IA & G1 & T1 & M0 & $\begin{array}{c}\text { Düşük grad, } \\
\text { A kompartman içi } \\
\text { Düşük grad, } \\
\text { B kompartman dışı } \\
\text { Yüksek grad, } \\
\text { IIA }\end{array}$ G1 \\
IIB & G2 & T2 & M0 & Mompartman i̧̧i \\
Yüksek grad, \\
IIIA-B
\end{tabular}

lezyonunda sınırlıdır ve çevre dokuya yayılmamıştır. Eğer tümör popliteal, aksilla, pelvis, elin orta kısmı veya ayak yerleşimli ise, Tip B olarak kabul edilir. ${ }^{[12]}$

Bilinmesi gereken konu şudur: Enneking sınıflaması, ameliyat öncesi dönemde kemoterapinin verilmediği ve bu nedenle kompartman rezeksiyonlarının daha sık uygulandığı yıllarda ortaya konmuştu. Bu durum, tümörün uzanımı ile uygulanan cerrahi; kemik sarkomunun evresi ile hasta sağkalımı arasında bir ilişki oluşmasına neden oluyordu. Ameliyat öncesi dönemde kemoterapinin kullanılır olması, kemik sarkomlarının yumuşak dokudaki uzanımlarının küçülmesine neden olmuş ve bu nedenle kompartman rezeksiyonuna olan ihtiyacı ve lokal nüksleri azaltmıştır. ${ }^{[3]}$

Enneking evreleme sistemi, ekstremitelerden köken alan mezenkimal kökenli tümörlerin evrelemesinde yararlıdır ama kemik iliği veya retiküloendotelyal sistem kökenli olan lenfoma, Ewing sarkoma, multipl miyelom, plasmositom ve metastatik karsinomların evrelemesinde kullanılması uygun değildir. ${ }^{[2,9]}$ Enneking sistemi ile spinal kolon tümörlerinde epidural kompartmanın durumu, spinal kord ve köklerin feda edilmesini gerektiren nörolojik bulguları ve spinal stabiliteyi değerlendirme konusunda da yetersizdir. Bu bölge için, WeinsteinBoriani-Biagini (WBB) etkinliğini kanıtlamış bir sistemdir. ${ }^{\left[{ }^{9}\right]}$ Sistem, tümörün tipi, büyüklüğü veya derinliği hakkında da bilgi vermez ve özellikle de yumuşak doku sarkomlarının evrelemesinde yetersiz kalır. ${ }^{[2,9]}$ Bu nedenle, onkoloji uzmanlarının belirli bir kesimi, her bölgede kullanılabildiği için, AJC sistemini kullanmayı tercih etmektedir. Bu sistem, TNMG sistemine dayanır: ${ }^{[1,2,9]}$ tümör büyüklüğü ve uzanımı $(T)$, lenf nodu tutulumu $(N)$, metastaz varlığı $(M)$ ve tümör tipi ve gradı $(G)$. Bu evreleme sisteminin orijinal halinin Enneking sisteminden asıl farkı, ifade edilmiş olunmasına rağmen, Evre IIl'ün tanımlanmamış olmasıdır. ${ }^{[1]} 2002$ yılında AJC sisteminde bir takım değişiklikler yapılmıştır. Evre I ve II için $8 \mathrm{~cm}$ sınırı getirilerek evrelerin $A$ ve $B$ olarak ayrılması sağlanmış, skip lezyon varlığı Evre III olarak değerlendirilmiş, Evre IVA akciğer metastazı varlığı, Evre IVB ise akciğer dışı uzak metastaz olarak ifade edilmiştir. ${ }^{[11,13]}$

illk tanımlanmış AJC sistemi evrelemesinin özellikleri (Tablo 3): ${ }^{[2,3,10]}$

G1: iyi diferansiye;

G2: orta düzeyde diferansiye;

G3: kötü diferansiye;

G4: indiferansiye

T1: tümör korteks içerisinde;

T2: tümör korteksi aşmış

N0: bölgesel lenf nodu tutulumu yok;

N1: bölgesel lenf nodu metastazı var

M0: uzak metastaz yok;

M1: uzak metastaz var 
Tablo 3. AJC sistemine göre kötü huylu kemik tümörlerinin cerrahi evrelemesi

\begin{tabular}{|c|c|c|c|c|c|}
\hline Evre & Grad & Uzanım & Lenf nodu metastazı & Uzak metastaz & Tanım \\
\hline IA & G1-G2 & $\mathrm{T} 1$ & No & Mo & \multirow{2}{*}{$\begin{array}{l}\text { Metastaz olmadan } \\
\text { düşük-orta gradlı }\end{array}$} \\
\hline IB & G1-G2 & $\mathrm{T} 2$ & No & Mo & \\
\hline IIA & G3-G4 & $\mathrm{T} 1$ & No & Mo & \multirow{2}{*}{$\begin{array}{l}\text { Metastaz olmadan } \\
\text { kötü-indiferansiye gradlı }\end{array}$} \\
\hline IIB & G3-G4 & $\mathrm{T} 2$ & No & Mo & \\
\hline III & Tanımlanmamış & & & & \\
\hline IVA & G1-4 & $\mathrm{T} 1-2$ & N1 & Mo & $\begin{array}{l}\text { Lenf nodu metastazının } \\
\text { olduğu tümör }\end{array}$ \\
\hline IVB & G1-4 & T1-2 & N0-1 & M1 & $\begin{array}{l}\text { Uzak metastazlı } \\
\text { herhangi bir tümör }\end{array}$ \\
\hline
\end{tabular}

Kemik tümörlerinin evrelemesinde bazı özel durumlar mevcuttur. Kemik tümörlerinin biyolojik davranışı sıklıkla değişkendir. Farklı olarak, kemik tümörlerindeki histolojik alt tip, o tümörün gradını da belirler. Alt gradlar içermeyen Ewing sarkomu, yüksek gradlı bir tümör olarak kabul edilirken, kondrosarkomlar tiplerine göre üç grada ayrılır ve evrelemesinde Evans klasik tümör gradlama sistemi kullanılır. Aynı şekilde osteosarkomlarda da, farklı morfolojik alt tiplerde farklı gradlar mevcuttur. Klasik osteojenik osteosarkom yüksek grad kabul edilirken, parosteal ve periosteal osteosarkomlar düşük grad olarak nitelendirilir. Kemik tümörlerinin gradlanmasında proliferatif aktivite, mitotik aktivite miktarı ve nekroz varlığı kullanılmaz. Atipik mitoz ise, grad açısından değerli bir kriterdir. ${ }^{[8]}$

\section{CERRAHI PRENSIPLER}

\section{Biyopsi alınması}

Ortopedik onkolojide tedaviye başlamadan önce kesin histolojik tanının konması ve cerrahi evreleme yapmak amacıyla materyal elde etme işlemine biyopsi adı verilir. Biyopsi, tedaviden önceki evrelemenin en son basamağıdır. ${ }^{[1,3]}$ Özellikle kötü huylu kemik ve yumuşak doku tümörlerinin tedavisinde güncel yaklaşım olan ekstremite koruyucu cerrahi yaklaşımların uygulanabilmesi için, biyopsinin doğru bir şekilde uygulanması ve yeterli materyal elde edilmesi şarttır. Ortopedik cerrahın cevaplaması gereken iki önemli sorudan birisi, kitlenin neresinden mutlaka parça almak gerektiği, diğeri ise bu bölgeye ulaşımı sağlayacak en uygun ve güvenli anatomik hattın neresi olduğudur. ${ }^{[3]}$ Uygun alandan alınmayan veya uygun olmayan anatomik giriş yerlerinden alınan biyopsi, ampütasyon kararı verilmesine bile neden olabilir. ${ }^{[1,6,14]}$

Biyopsi konusu ile ilgili Mankin ve arkadaşlarının 1982 yılında yaptıkları çalışma dikkat çekicidir.
Çalışma sonucunda, kas ve iskelet sistemini ilgilendiren tümör biyopsilerinin \%18,2'sinde tanının yanlış konduğu, \%10,3'ünde yetersiz veya değerlendirilemeyecek materyal alındığı ve $\% 17,3$ 'ünde yara komplikasyonu geliştiği gösterilmiştir. Bu komplikasyonlar nedeniyle olguların \%18,2'sinde tedavi planının değiştirilmek durumunda kalındığı ve \%4,5 olguda ampütasyon uygulandığı ortaya çıkmıştır. Bunun üzerine, kas ve iskelet sistemini ilgilendiren tümör şüphesi olduğunda, biyopsinin, tedaviyi sonuçlandırabilecek bir merkezde yapılması başta olmak üzere bir takım önlemler önerilmiştir. Önerilerin etkilerini araştırmak için yapılan başka bir çalışmada ise, önerilere rağmen oranların çok da değişmediği gözlenmiş ve bu konu, günümüze kadar tartışılmaya devam etmiştir. ${ }^{[15,16]}$

Bahsi geçen çalışmalardan da anlaşılacağı üzere, biyopsi, son derece önemli bir konudur ve nihai tedavi kadar dikkatli davranılması gereken bir uygulamadır. Biyopsiyi uygulamak teknik olarak kolay olabilir; ancak önemli olan, biyopsi endikasyonunu koyabilmek, kitlenin neresinden mutlaka parça alınması gerektiğini bilmek, anatomik yaklaşım konusunda fikir sahibi olabilmek ve nasıl bir yöntemle biyopsinin alınacağına karar vermektir. Biyopsi endikasyonu vermeye kadar geçen planlama açısından literatürde belirtilmiş stratejiler mevcuttur. ${ }^{[1,17]}$ Biyopsi alınmasına karar verildiğinde, patolojik tanının uygun bir şekilde elde edilebilmesi için, cerrah ve patoloğun, biyopsi öncesinde hastanın hikayesini, radyolojik incelemelerini ve ayırıcı tanıları birlikte incelemeleri önerilmektedir. ${ }^{[1]}$

Ortopedik onkolojide biyopsi, kapalı veya açık uygulanabilir. Kapalı biyopsiler ince iğne aspirasyon biyopsisi ve core-needle biyopsi (tru-cut veya Jhamshidi iğnesi ile) olarak ikiye ayrilır. ${ }^{[14]}$ Deneyimli bir ortopedik cerrahın elinde, iğne biyopsileri ile \%90 yeterli materyal alımı sağlanabilir. İnce iğne aspirasyon biyopsileri \%90 
oranında malignite ayrımı yapmaya yardımcı olsalar da spesifik olarak tümörün tipini belirlemede yetersiz kalabilir. ${ }^{[11]}$ Hangi yöntemle alınırsa alınsın, biyopsilerde uyulması gereken bazı kurallar vardır. Lezyona ulaşılabilecek en kısa yol seçilmelidir. ${ }^{[6]}$ Bu yol, biyopsi sonrasında uygulanması muhtemel cerrahi müdahaleye engel olmayacak mümkün olan en kısa yol olarak değerlendirilmeli, anatomik olarak en kısa hat olarak düşünülmelidir. Eğer ulaşımı zor olan bir bölge ise, biyopsi BT veya MR altında da uygulanabilir. Biyopsi yolu, tümör hücreleri ile kontamine kabul edildiğinden dolayı, biyopsi iğnesinin giriş noktası, esas tedavinin yapılacağı insizyon hattı üzerinde olmalıdır. ${ }^{[3,14]}$ Tek bir kas kitlesi içerisinden geçilmelidir. Bu şekilde kötü huylu bir tümörün tedavisinde sadece o kasın çıkarılması, morbiditenin en az düzeyde kalmasına yardımcı olacaktır. Nörovasküler yapılara olabildiğince uzak kalınarak biyopsi alınmalıdır. ${ }^{[6]}$ Tek giriş deliğinden girilmeli ancak birden fazla noktadan materyal alınmalıdır. Materyal alınması esnasından tümör ile sınırlı kalmak ve karşı kompartmana geçmemek esastır. ${ }^{[14]}$ Eklem kapsülünden geçilmemesine özen gösterilmelidir. Yeterli miktarda materyal alınması, tanının doğru konulması açısından oldukça önemlidir.

Açık biyopsi (insizyonel veya eksizyonel olarak) insizyon yapılarak alınan ve fazla materyal alınabilmesi nedeniyle yanlış tanı ihtimalinin azaldığı biyopsi çeşididir. İ̆ne biyopsileri ile tanı konulamadığında veya konulan tanı hastanın klinik ve radyolojik özellikleri ile uyumlu olmadığı zaman, açık biyopsiye geçilmelidir. ${ }^{[3,18]} \mathrm{Bu}$ işlem esnasında longitudinal ve küçük insizyonlar tercih edilmeli, transvers insizyon uygulanmasından kesinlikle kaçınılmalıdır. Alınan fazla doku, patolog tarafından hücresel morfolojik özelliklerin ve doku mimarisinin incelenmesine, immünohistokimyasal, sitogenetik, moleküler genetik, flow sitometri ve elektron mikroskopisi gibi ayrıntılı incelemelere olanak sağlayarak, sadece tanı konmasına yardımcı olmakla kalmaz, gelecek yıllar içerisinde uygulanabilecek yeni kemoterapötik ilaçların oluşturulmasına da ışık tutar. ${ }^{[3]}$ Kemikte ovoid veya yuvarlak pencereler açılmalı, patolojik kırıklara neden olabilen keskin açılı pencereler tercih edilmemelidir. [11] Pencerenin boyutunun büyütülmesi gereken durumlarda, pencerenin eni değil, boyu uzatılmalıdır. ${ }^{[3]}$ isşlem sonunda, kemik pencere az miktardaki kemik çimentosu ile kapatılarak hematomun yumuşak dokuya sızması engellenmelidir. ${ }^{[11,18]}$ Kemik çimentosunun fazla kullanılması, tümörün kemik içerisinde de aşağı veya yukarı doğru itilmesine neden olabileceği için, dikkatli olunmalıdır. ${ }^{[11]}$ Biyopsi alınan yerden kültür materyali, kültür alınan yerden biyopsi alınmasına özen gösterilmelidir. Kötü huylu kemik tümöründen alınacak biyopsinin, kitlenin büyümesini hızlandıracağına veya metastazına neden olacağına dair herhangi bir veri bugüne kadar elde edilemese de, lokal nükse neden olabileceği bilinmektedir. ${ }^{[3,18]}$ Bu tarz bir lokal nüks ihtimali, elbette ki biyopsi yolunun genişliği ve hemostaz problemlerinden dolayı açık biyopsilerde daha fazladır. Biyopsi alınacak olan ekstremitede turnike kullanılacaksa, kanın ekstremiteden boşaltılması elevasyon ile sağlanmalıdır. ${ }^{111]}$ işlem sonunda turnike indirilmesini takiben hemostaz çok iyi sağlanmalı, dren hattının insizyon hattı içinde kalmasına dikkat edilmelidir. Yara dudakları sıkı bir şekilde dikilmeli, geniş retansiyon dikişlerinden kaçınılmalıdır. ${ }^{[11,14]}$

Kesin tedavi için biyopsi sonucunun beklenmesi, tedavi şeklinin yanlış olmaması açısından oldukça değerlidir. Kemik biyopsilerinin frozen patoloji ile anında incelenmesinin her zaman uygun olmadığı akıldan çıkarılmamalıdır. Metastaza bağlı olduğu düşünülen patolojik bir kırık durumunda ise, ince iğne ile alınacak bir aspirasyon materyalinin frozen patolojik incelemesinde kötü huylu hücre görünmesi durumunda, biyopsi sonucunun beklemesine gerek kalmadan metastaza bağlı patolojik kırığın tedavisine hemen başlanabilir. Patolojik incelemenin şüpheli olduğu durumlarda, ameliyatı ertelemek, her zaman en akılcı tutum olacaktır.

Kemik tümörlerini ilgilendiren bazı durumlarda biyopsi almadan, kesin tedaviye geçilebilir. Osteoid osteoma ve osteokondromun radyolojik incelemelerdeki görüntüleri, sıklıkla tipiktir ve böyle durumlarda biyopsiye gerek olmadan tedavi edilebilir.[11] Akıldan çıkarılmaması gereken bir nokta, her ne kadar görünümleri tipik de olsa, zaman zaman bu iyi huylu tümörlerin ayırıcı tanılarına başka rahatsızlıkların dahil olabileceğidir. Örnek olarak, osteoid osteomayı subakut osteomiyelitten ayırt etmek bazen güç olabilir. ${ }^{[11]}$ En ufak şüphede, işlem sadece biyopsi yapmak olmalıdır. Biyopsi olmadan kesin tedavinin uygulanabileceği bir başka durum, proksimal fibula veya distal ulnanın lezyon tarafından genişlediği ve ağı yarattığı durumdur. $\mathrm{Bu}$ yerleşimlerde, lezyon kemik içerisinde sınırlı ise ve ağrı varsa, biyopsi uygulamadan, iyi huylu - kötü huylu ayrımı yapmadan, doğrudan kemik rezeksiyonu kararı verilebilir. ${ }^{[11]}$ Şüphe duyulan durumlar, bu tanımlama dışında tutulmalıdır.

\section{Cerrahi sınır ve rezeksiyon tipi}

Gelişen radyolojik inceleme teknikleri, radyoterapi ve kemoterapide elde edilmiş olan ilerlemeler ve cerrahi tekniklerdeki yenilikler, son yıllarda kötü huylu kemik tümörlerinin cerrahi tedavisinde ekstremite koruyucu yöntemlerin ampütasyonun önüne geçmesindeki en büyük etkendir. ${ }^{[11]}$ Simon'a göre osteosarkomlu bir hastada ampütasyon veya ekstremite koruyucu 
cerrahi kararı verme aşamasında olan bir ortopedik cerrahın yanıtlarını bulması gereken dört önemli soru vardır: ${ }^{[19]}$ Seçilecek tedavi sağkalımı ne derecede etkileyecek? Kısa ve uzun dönemlerde morbidite arasındaki fark ne kadar olacak? Kurtarılmış ekstremitenin fonksiyonları, ortezle elde edilecek fonksiyona göre ne derecede olacak? Düşünülmesi gereken psikososyal durumlar var mı?

Günümüz koşullarındaki veriler, klasik osteosarkomda uygulanan kemoterapi ve cerrahi tedavinin birlikte uygulandığı rejimin uzun dönem sağkalımı \%20'lerden \%70'lere kadar çıkarttığını göstermektedir.[11] Distal femurun klasik osteosarkomunda her ne kadar kalça dezartikülasyonu ile en düşük düzeyde lokal nüks oranları mevcut olsa da, hangi cerrahi yöntemin daha iyi bir sağkalım oranına sahip olacağı konusunda yapılmış bir çalışma yoktur. Önemli olan kitlenin geniş sınırlarla çıkarılması ve bu aşamadan sonra hastanın fonksiyonel durumunun ne olacağıdır.

Ampütasyon ve ekstremite koruyucu cerrahi yöntemlerinin kendilerine has komplikasyonları ve zorlukları vardır. Ampütasyon uygulanan hastalarda, enfeksiyon, yara problemleri, fantom ağrıları ve ortez problemleri daha sık görülürken, ekstremite koruyucu cerrahi hem ameliyat esnasında hem ameliyat sonrasında daha morbid bir yöntemdir: enfeksiyon, yara kapanma problemleri, derin ven trombozu, protez enfeksiyonu, protez gevşemesi, biyolojik rekonstrüksiyonlarda greft kaynamaması, greft kırılması, ekstremiteler arası boy uzunlukları arasında eşitsizlik gibi birçok komplikasyon sayılabilir. Ekstremite koruyu cerrahi uygulanmış olan hastaların üçte birinde ilerleyen dönemlerde ampütasyon gerekebileceği bilgisi akıldan çıkarılmamalıdır.

Kemik sarkomlarının lokalizasyonu ve büyüklüğü de tedavi stratejisi açısından hastanın kaderini çizen etmenlerden birisidir. Asıl önemli olan, kitlenin geniş sınırlarla çıkarılabilip çıkarılamayacağı sorusunun yanıtlanmasıdır. Bu noktada, rezeksiyon sınır tiplerinin bilinmesi, oldukça önemlidir.

Kemik ve yumuşak doku sarkomları santral olarak büyüme gösterdikleri için, çevre dokuların komprese olması nedeniyle etraflarında normal dokular ve inflamatuvar hücreler ile birlikte reaktif fibrovasküler zon oluşur. Bu zon aynı zamanda psödokapsül olarak da değerlendirilebilir. Reaktif zonun kalınlığı yüksek gradlı sarkomlarda incedir. Bu ince reaktif zon, tümör tarafindan delinecek olursa, çevre dokularda lokal metastaz (skip metastaz) gelişebilir. ${ }^{[20]}$ Radyolojik inceleme yapılırken, sadece tümörün olduğu alanın lokal olarak incelenmesi, yanlış değerlendirmelere neden olabilir. Bu nedenle, yüksek gradlı kemik sarkomlarında, tüm ekstremitenin radyografik yöntemlerle incelenmesi, evrelemenin doğru yapılabilmesi ve tedavi planlamasının uygun olması açısından kritik öneme sahiptir. Skip metastazlar, dolaşıma geçmemiş mikrometastaz olarak da değerlendirilebilir. Evrelemeyi doğrudan etkileyen skip metastazlar, cerrahi sınırın temiz olduğu olgulardaki lokal nükslerin nedeni olarak da düşünülmektedir. ${ }^{[3]}$ Düşük gradlı kemik sarkomlarında skip metastazlar yok denecek kadar azdır. Kendi bulunduğu kompartmanda büyümeye devam eden kemik sarkomları, ilerleyen dönemde kortikal bariyeri aşacak olursa, kompartman dışı olarak değerlendirilmeleri gerekir. ${ }^{[20]} \mathrm{Bu}$ durum, tümörün evresini değiştirecek bir nedendir.

Tüm bu ön bilgiler ışığında, kötü huylu kemik tümörlerine yapılacak olan cerrahi yaklaşımlarda, lokal nüksün önüne geçmenin temel yolu, kitlenin temiz sınırlar ile çıkartılmasıdır. Bunun için, rezeksiyon tiplerinin bilinmesi önemlidir.

Enneking, dört farklı rezeksiyon tanımlamıştır. ${ }^{[21]}$ Bunlar; intralezyonel, marjinal, geniş ve radikal eksizyonlardır (Şekil).

İntralezyonel eksizyon, tümörün içerisinde çalışılarak tümör dışarıya çıkarıldığı veya kürete edilerek temizlendiği yöntemdir. Kötü huylu tümörlerde genellikle bu yöntemin kullanılması sakıncalı olmakla birlikte, iyi huylu lezyonlarda ve Grad 1 kondrosarkom gibi düşük gradlı bazı kötü huylu tümörlerde tercih edilebilir. ${ }^{20]}$ Bazı metastatik kitlelerde debulking amacıyla da intralezyonel çalışılabilir. ${ }^{[11]}$ İntralezyonel eksizyonlara uygun tümörlerde, tümör kavitesinin duvarında gözle görülemeyen tümöral hücrelerin yok edilmesi için sıklıkla lokal adjuvan tedaviler (koterizasyon, argon koterizasyon, hidrojen peroksit, yüksek hızlı burr, sıvı nitrojen ile kriyoterapi, fenol, etanol, alkol, kemik çimentosu gibi) ilave edilir. ${ }^{[20]}$

Marjinal eksizyon, tümörün reaktif zonundan veya psödokapsülünden sınırlandırılarak çıkarılma yöntemidir. Omurga gibi tümörün yerleştiği bölgede geniş olduğu veya radikal eksizyonun oldukça zor olduğu bölgeler dışında, kötü huylu kemik tümörlerinde tercih edilen bir yöntem değildir. ${ }^{[20]}$ Kötü huylu kitlelerde psödokapsülün satellit lezyon içerebileceği ve lokal nükse neden olabileceği unutulmamalıdır. Özel durumlarda, neoadjuvan radyoterapi veya kemoterapi ile kitlelerin ampütasyon yerine marjinal eksizyon ile çıkartılması mümkün olabilir ancak lokal nüks ihtimali göz ardı edilmemelidir. ${ }^{[11]}$

Geniş eksizyon, tümörün reaktif zonu veya yalancı kapsülü ve bunların üzerinde bulunan sağlam dokuların bir kısmı ile birlikte çıkarıldığı yöntemdir. Yüksek gradlı kemik sarkomlarında genellikle bu eksizyon tercih edilerek, tümörlü doku, üzerinde sağlam kas 


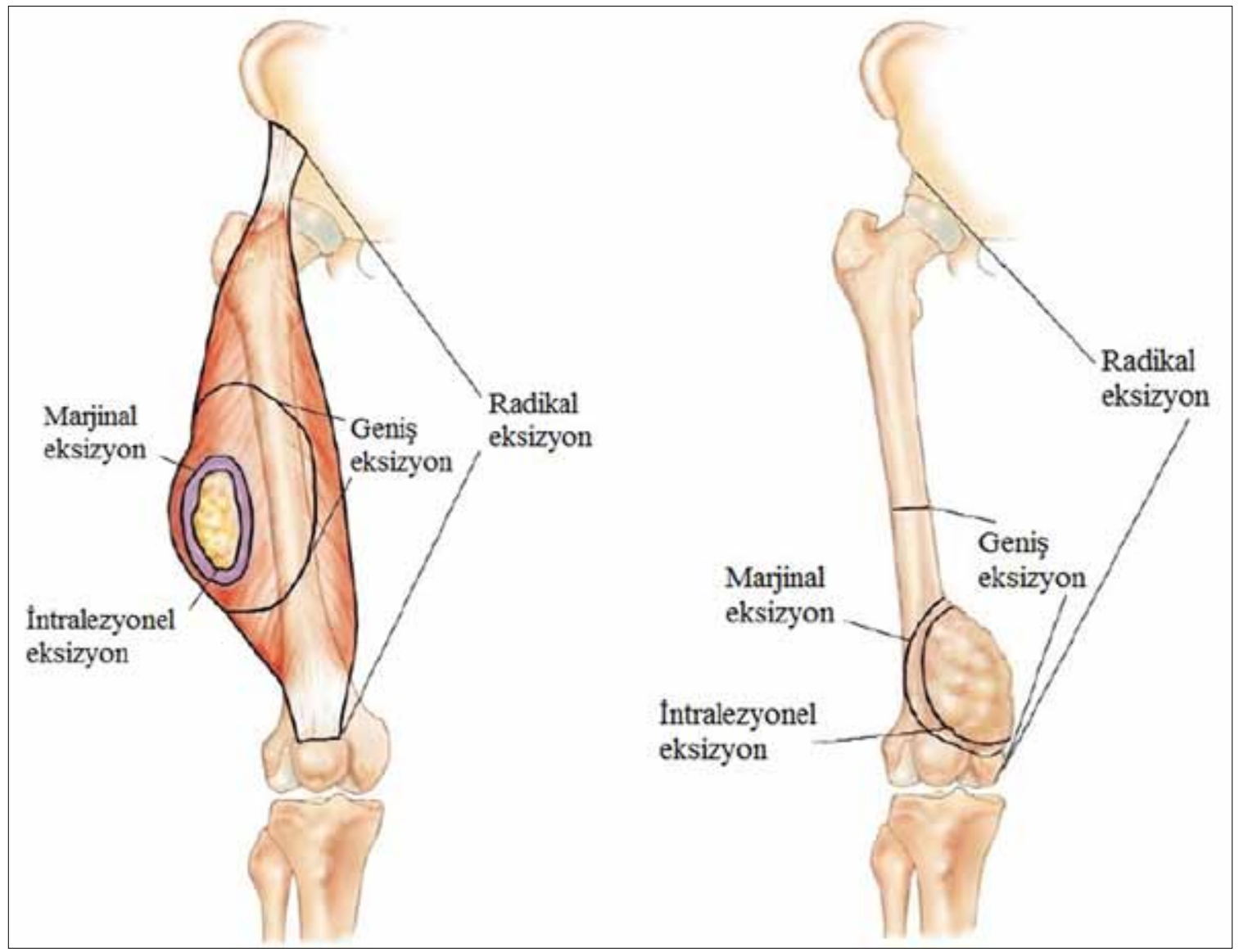

Şekil. Yumuşak doku ve kemik tümörlerinde rezeksiyon tipleri[20]

ve/veya fasya ile birlikte çıkarılır. ${ }^{[20]} \mathrm{Ne}$ kadar sağlam doku, yüksek gradlı kitleler ile birlikte çıkarılmalı sorusu halen tartışmalıdır. ${ }^{[3,11]}$ Her ne kadar zaman zaman bunu sağlamak zor olsa da, Malawer ve arkadaşları yumuşak doku ve kemik sarkomlarında bu sağlam dokunun birkaç santimetre olmasının arzu edildiğine dikkat çekmişlerdir. ${ }^{[3]}$

Radikal eksizyon, tümörü saran reaktif zonun, psödokapsül ile birlikte tüm kemik ve/veya eklem ve tümörün bulunduğu kompartmandaki tüm kasların çıkarıldığı eksizyon tipidir. ${ }^{[20]}$ Anatomik bariyerleri aşmış veya ekleme açılmış olan kemik sarkomlarında tercih edilen bir yöntem olup, fonksiyonel açıdan hastada ciddi sekel bırakabilen tedavi yöntemidir. Uygun bir radikal eksizyon sonrasında skip metastaz ihtimali kalmaz. ${ }^{[3]}$

Yüksek gradlı kemik sarkomlarının cerrahi tedavisinde sıklıkla tercih edilen geniş veya radikal eksizyonlarda dikkat edilmesi gereken nokta, eksizyon esnasında tümörün bulunduğu dokunun açılmaması ve etrafa yayılmamasıdır. Tümörün tek parça halinde çıkarılması, etrafında sağlam doku olması, tümörlü dokunun cerrahi malzemeler ile temas halinde olmaması oldukça önemlidir. Yapılacak olan eksizyonun miktarı, ameliyat öncesinde uygun endikasyonlar ve tercih edilecek kemoterapi veya radyoterapi rejimleri ile küçültülebilir.

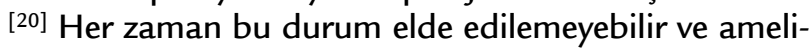
yat esnasında ciddi fonksiyon kayıplarına neden olabilecek boyutlarda eksizyon gereksinimi ortaya çıkabilir. Bu tarz ameliyatlardan önce cerrahi planlamanın çok iyi yapılması, ameliyat esnasında damar-sinir rekonstrüksiyonları ve cerrahi sahanın kapatılması esnasında cilt ve kas flebi gereksinimlerine göre ön hazırlıkların yapılması, hastanın fonksiyonlarını daha hızlı kazanması açısından akılda tutulmalıdır. Tüm çabalara rağmen, zaman zaman ekstremite koruyucu cerrahiyi bu tip rezeksiyonlar ile elde etmenin mümkün olmadığı ve radikal rezeksiyonlara rağmen lokal nüks ihtimalinin çok yüksek olduğu ileri evre olgular ile karşılaşılmaktadır. Bu gibi durumlarda, ampütasyon gereksinimi mutlaka gözden geçirilmelidir. ${ }^{[20]}$

Kötü huylu kemik sarkomlarında geniş veya adjuvan ve/veya neoadjuvan onkolojik tedavilerle birlikte uygulanacak marjinal rezeksiyon sonrası rekonstrüksiyonlar, 
osteoartiküler allogreft, endoprotez kullanımı veya allogreft-protez kompozit rekonstrüksiyonlar gibi yöntemlerle elde edilebilir. ${ }^{[11,22]}$ Geniş ameliyat sahası, uzun ameliyat süreleri, ciddi kan kayıpları ve önceden kemoterapi veya radyoterapi uygulanmış olması nedeniyle, bu tarz ameliyatlar özellikle yara kapanma problemleri, yara dudaklarında nekroz ve yüzeyel/derin enfeksiyon gibi komplikasyonlara açıktır. Bazı komplikasyonlar ise, seçilecek yöntemle ilişkilidir. Greft kaynamaması, greft kırılması, boy uzunluk eşitsizlikleri, dejeneratif eklem rahatsızlıkları, dislokasyon, bağ yetersizlikleri gibi problemler osteoartiküler allogreftlerde görülen ciddi sorunlardır. Protez uygulamaları hastanın normal hayatına daha hızı geri dönme ve erken rehabilitasyon şansı tanısa da, polietilen problemleri, enfeksiyon, gevşeme, stem altından gelişen kırıklar sürecin yaratabileceği bazı sorunlardandır. ${ }^{[11]}$

Pediatrik hasta grubunda, uzunluk farkından doğan sorunlar basit uzatma veya karşı taraf epifizyodezi ile engellenmeye çalışılsa da çok ufak yaşlardaki çocukların kemik sarkomlarında rotasyonplasti ve ampütasyon seçenekler arasındadır. ${ }^{[1,23]}$ Çocuk yaş grubundaki kemiklerin oldukça ufak boyutlarda olması, uygun allogreft bulunamaması sorununu da beraberinde getirir. Son dönemlerde, uzayabilen megaimplantlar, çocuk yaş grubu için tedaviyi farklı bir boyuta taşımış gibi görünse de, bu implantların ömrü, yaratabileceği sorunlar ve hastanın sağkalımı gibi konuların birlikte düşünülmesi ve buna göre davranılması gerekmektedir. ${ }^{[11,24]}$

\section{KAYNAKLAR}

1. Peabody TD, Gibbs CP Jr, Simon MA. Evaluation and staging of musculoskeletal neoplasms. J Bone Joint Surg Am 1998;80(8):1204-18.

2. Ruggieri P. Staging. In: Picci P, Manfrini M, Fabbri N, Gambarotti M, Vanel D, editors. Atlas of Musculoskeletal Tumors and Tumorlike Lesions. The Rizzoli Case Archive. Switzerland: Springer International Publishing; 2014. p.xix-xxii.

3. Shmookler B, Bickels J, Jelinek J, Sugarbaker P, Malawer MM. Bone and Soft-tissue Sarcomas: Epidemiology, Radiology, Pathology and Fundamentals of Surgical Treatment. In: Malawer MM, Sugarbaker PH, editors. Musculoskeletal Cancer Surgery. Treatment of Sarcomas and Allied Diseases. Dordrecht: Kluwer Academic Publishers; 2001. p.3-36.

4. American Joint Committee on Cancer. Gynecologic Sites. In: Fleming ID, Cooper JS, Henson DE, Hutter RVP, Kennedy BJ, Murphy GP, O'Sullivan B, Sobin LH, Yarbro JW, editors. AJCC Cancer Staging Manual, 5th edition. Philadelphia: LippincottRaven; 1997. p.181.

5. Enneking WF, Spanier SS, Goodman MA. Current concepts review. The surgical staging of musculoskeletal sarcoma. J Bone Joint Surg Am 1980;62(6):1027-30.

6. Anderson MW, Temple HT, Dussault RG, Kaplan PA. Compartmental anatomy: relevance to staging and biopsy of musculoskeletal tumors. AJR Am J Roentgenol 1999;173(6):1663-71.
7. Parsons TW 3rd, Filzen TW. Evaluation and staging of musculoskeletal neoplasia. Hand Clin 2004;20(2):v,137-45.

8. Dervişoğlu S. Patolojik Değerlendirmede Karşılaşılan Sorunlar. In: Dabak N, editör. Multidisipliner Yaklaşımla Kemik ve Yumuşak Doku Tümörleri. Ankara: BAYT Bilimsel Araştırmalar Basın Yayın ve Tanıtım Ltd. Şti; 2013. p.83-94.

9. Jawad MU, Scully SP. In brief: classifications in brief: Enneking classification: benign and malignant tumors of the musculoskeletal system. Clin Orthop Relat Res 2010;468(7):2000-2. CrossRef

10. American Joint Committee on Cancer. Bone. In: Fleming ID, Cooper JS, Henson DE, Hutter RVP, Kennedy BJ, Murphy GP, O'Sullivan B, Sobin LH, Yarbro JW, editors. AJCC Cancer Staging Manual 5th edition. Philadelphia: Lippincott-Raven; 1997. p.143-7.

11. Heck RK Jr. General Principles of Tumors. In: Canale ST, Beaty JH, editors. Campbell's Operative Orthopaedics, 11th edition. Philadelphia: Mosby Elsevier; 2008. p.775-854.

12. Erler K. Kemik veya Yumuşak Doku Tümörlerine Tanısal Yaklaşım. In: Dabak N, editör. Multidisipliner Yaklaşımla Kemik ve Yumuşak Doku Tümörleri. Ankara: BAYT Bilimsel Araştırmalar Basın Yayın ve Tanıtım Ltd. Şti; 2013. p.17-28.

13. American Joint Committee on Cancer. Bone. In: Greene FL, Page DL, Fleming ID, Fritz AG, Balch CM, Haller DG, Morrow $M$, editors. AJCC Cancer Staging Handbook: from the AJCC Cancer Staging Manual, 6th edition. New York: Springer; 2002. p.213-5.

14. Bülbül AM. Kemik ve Yumuşak Doku Tümörlerinde Biyopsi. In: Dabak N, editor. Multidisipliner Yaklaşımla Kemik ve Yumuşak Doku Tümörleri. Ankara: BAYT Bilimsel Araştırmalar Basın Yayın ve Tanıtım Ltd. Şti; 2013. p.71-4.

15. Mankin HJ, Lange TA, Spanier SS. The hazards of biopsy in patients with malignant primary bone and soft-tissue tumors. J Bone Joint Surg Am 1982;64(8):1121-7.

16. Mankin HJ, Mankin CJ, Simon MA. The hazards of the biopsy, revisited. Members of the Musculoskeletal Tumor Society. J Bone Joint Surg Am 1996;78(5):656-63.

17. Simon MA, Finn HA. Diagnostic strategy for bone and softtissue tumors. J Bone Joint Surg Am 1993;75(4):622-31.

18. Errani C, Traina F, Perna F, Calamelli C, Faldini C. Current concepts in the biopsy of musculoskeletal tumors. ScientificWorldJournal 2013;2013:538152. CrossRef

19. Simon MA. Limb salvage for osteosarcoma. J Bone Joint Surg Am 1988;70(2):307-10.

20. Özbarlas Serdar. Kemik ve Yumuşak Doku Tümörlerinde Cerrahi Sınırlar, Rezeksiyon Tipleri ve Lokal Adjuvanlar. In: Dabak N, editör. Multidisipliner Yaklaşımla Kemik ve Yumuşak Doku Tümörleri. Ankara: BAYT Bilimsel Araştırmalar Basın Yayın ve Tanıtım Ltd. Şti; 2013. p.95-100.

21. Enneking WF, Spanier SS, Goodman MA. A system for the surgical staging of musculoskeletal sarcoma. Clin Orthop Relat Res 1980;(153):106-20.

22. Campanacci L, Manfrini M, Colangeli M, Alí N, Mercuri M. Long-term results in children with massive bone osteoarticular allografts of the knee for high-grade osteosarcoma. J Pediatr Orthop 2010;30(8):919-27. CrossRef

23. Forni C, Gaudenzi N, Zoli M, Manfrini M, Benedetti MG, Pignotti E, Chiari P. Living with rotationplasty - quality of life in rotationplasty patients from childhood to adulthood. J Surg Oncol 2012;105(4):331-6. doi: 10.1002/jso.22088

24. Ruggieri $P$, Mavrogenis AF, Pala E, Romantini M, Manfrini M, Mercuri M. Outcome of expandable prostheses in children. J Pediatr Orthop 2013;33(3):244-53. CrossRef 